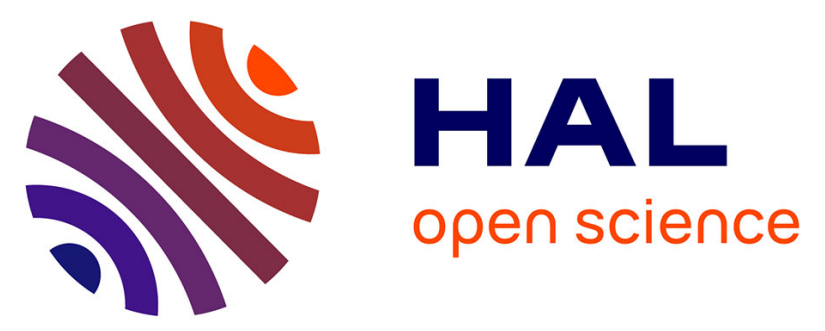

\title{
Feasibility and efficacy of early lung cancer diagnosis with chest computed tomography in HIV-infected smokers
}

\author{
Alain Makinson, Sabrina Eymard-Duvernay, François Raffi, Sophie Abgrall,
} Sébastien Bommart, David Zucman, Florent Valour, Antoine Chéret, Isabelle Poizot-Martin, Claudine Duvivier, et al.

\section{To cite this version:}

Alain Makinson, Sabrina Eymard-Duvernay, François Raffi, Sophie Abgrall, Sébastien Bommart, et al. Feasibility and efficacy of early lung cancer diagnosis with chest computed tomography in HIVinfected smokers. AIDS. Official journal of the international AIDS Society, 2016, 30 (4), pp.573-582. 10.1097/QAD.0000000000000943 . hal-01274227

\section{HAL Id: hal-01274227}

\section{https://hal-univ-rennes1.archives-ouvertes.fr/hal-01274227}

Submitted on 10 Dec 2019

HAL is a multi-disciplinary open access archive for the deposit and dissemination of scientific research documents, whether they are published or not. The documents may come from teaching and research institutions in France or abroad, or from public or private research centers.
L'archive ouverte pluridisciplinaire HAL, est destinée au dépôt et à la diffusion de documents scientifiques de niveau recherche, publiés ou non, émanant des établissements d'enseignement et de recherche français ou étrangers, des laboratoires publics ou privés. 
archives-ouvertes

\title{
Feasibility and efficacy of early lung cancer diagnosis with chest computed tomography in HIV-infected smokers
}

\author{
Alain Makinson, Sabrina Eymard-Duvernay, François Raffi, Sophie Abgrall, \\ Sébastien Bommart, David Zucman, Florent Valour, Antoine Chéret, Isabelle \\ Poizot-Martin, Claudine Duvivier, et al.
}

\section{To cite this version:}

Alain Makinson, Sabrina Eymard-Duvernay, François Raffi, Sophie Abgrall, Sébastien Bommart, et al.. Feasibility and efficacy of early lung cancer diagnosis with chest computed tomography in HIV-infected smokers. AIDS, Lippincott, Williams \& Wilkins, 2016, 30 (4), pp.573-582. 10.1097/QAD.0000000000000943 . hal-01274227

\section{HAL Id: hal-01274227}

\section{https://hal-univ-rennes1.archives-ouvertes.fr/hal-01274227}

Submitted on 10 Dec 2019

HAL is a multi-disciplinary open access archive for the deposit and dissemination of scientific research documents, whether they are published or not. The documents may come from teaching and research institutions in France or abroad, or from public or private research centers.
L'archive ouverte pluridisciplinaire HAL, est destinée au dépôt et à la diffusion de documents scientifiques de niveau recherche, publiés ou non, émanant des établissements d'enseignement et de recherche français ou étrangers, des laboratoires publics ou privés. 


\title{
Feasibility and efficacy of early lung cancer diagnosis with chest computed tomography in HIV-infected smokers
}

\author{
Alain Makinson $^{a, b, c}$, Sabrina Eymard-Duvernay ${ }^{a}$, François Raffi ${ }^{d}$, \\ Sophie Abgrall ${ }^{\mathrm{e}, \mathrm{f}}$, Sébastien Bommart ${ }^{\mathrm{g}, \mathrm{h}}$, David Zucman ${ }^{\mathrm{i}}$, \\ Florent Valour', Antoine Cheret ${ }^{\mathrm{k}}$, Isabelle Poizot-Martin ${ }^{\mathrm{l}, \mathrm{m}}$, \\ Claudine Duvivier ${ }^{\text {n,o,p }}$, Jean-Marc Mauboussin ${ }^{q}$, Fabrice Bonnet ${ }^{r}$, \\ Pierre Tattevin $^{\text {s }}$ Jacques Reynes ${ }^{a, b}$, Vincent Le Moing ${ }^{a, b}$, for the ANRS \\ EP48 HIV CHEST study Team
}

\begin{abstract}
Objective: Lung cancer screening with chest computed tomography (CT) is beneficial in smokers aged 55 to 74 years. We studied the risks, benefits and feasibility of early lung cancer diagnosis with $\mathrm{CT}$ in HIV-infected smokers.

Design and setting: French, multicentre, single round chest CT study in France, realized between February 2011 and June 2012.

Participants: Patients were HIV-infected smokers at least 40 years, at least 20 packyears, with a $\mathrm{CD}^{+}{ }^{+} \mathrm{T}$-lymphocyte nadir count below 350 cells $/ \mu$ l.

Intervention: Single chest CT with a proposed standardized workup algorithm of positive images.

Main outcome measure: The outcome was the number of histologically proven lung cancers diagnosed by CT with a 2-year follow-up.

Results: Median age of the 442 included patients was 49.8 years, $81.6 \%$ were under 55 years, $84 \%$ were men, median smoking was 30 pack-years, median nadir and last CD4 ${ }^{+}$ cell counts were 168 and 574 cells/ $\mu \mathrm{l}$, respectively, and $90 \%$ of patients had a plasma HIV RNA below 50 copies/ml. A positive image at baseline was reported in 94 (21\%) patients, and $15(3.4 \%)$ patients had 18 invasive procedures with no serious adverse events. Lung cancer was diagnosed in 10 patients (six at early stages), of which nine (2.0\%, 95\% confidence interval: $0.9-3.8)$ were $\mathrm{CT}$ detected, and eight in patients below 55 years.
\end{abstract}

\footnotetext{
a University Montpellier, UMI233-IRD/U1175-INSERM, Montpellier, ${ }^{b}$ Department of Infectious and Tropical Diseases, Montpellier University Hospital, Montpellier, ' ${ }^{\mathrm{C}}$ epartment of Internal Medicine, Clinique Beau-Soleil, Montpellier, ${ }^{\mathrm{d}} \mathrm{CMIT}$, Paris, e Department of Infectious Diseases and Tropical Medicine, AP-HP, Avicenne Hospital, Bobigny, ${ }^{\mathrm{f}}$ Department of Internal Medicine, AP-HP, Antoine Béclère Hospital, Clamart, ${ }^{8}$ Department of Medical Imaging, Lapeyronie Hospital, University Hospital Montpellier, Montpellier, hPhyMedExp, University of Montpellier, INSERM U1046, CNRS UMR 9214 Montpellier, 'Department of HIV, AP-HP, Foch Hospital Suresnes, I'Infectious and Tropical Disease Unit, University Hospital de la Croix Rousse, Lyon, ${ }^{k}$ Department of Infectious Diseases, Tourcoing Hospital, Tourcoing, 'Aix-Marseille University, APHM Sainte-Marguerite Hospital, Immuno-Hematology Clinic, Marseille, ${ }^{\mathrm{m}}$ Inserm U912 (SESSTIM), Marseille, ${ }^{\mathrm{n}}$ EA 7327, Paris Descartes University-Sorbonne Paris Cité, Paris, ${ }^{\circ}$ Department of Infectious Diseases and Tropical Medicine, AP-HP, Necker-Enfants malades Hospital, Infectiology Centre Necker-Pasteur, Paris, PIHU Imagine, Paris, 9Infectious and Tropical Diseases Unit, Nîmes University Hospital, Nîmes, 'Department of Internal Medicine and Infectious Diseases, University Hospital Bordeaux, INSERM U897, Bordeaux, and 'Infectious Diseases and Intensive Care Unit, Pontchaillou University Hospital, Rennes, France.

Correspondence to Alain Makinson, Department of Infectious and Tropical Diseases, Montpellier University Hospital, UMI233IRD/U1175-INSERM, France.
}

Tel: +0033467337705; fax: +0467337709; e-mail: a-makinson@chu-montpellier.fr 
Conclusion: Early lung cancer diagnosis with CT in HIV-infected smokers was feasible, safe, and yielded a significant number of cancers. Lung cancer screening of HIVinfected smokers with an important history of immunodeficiency revealed a substantial number of cancers at younger ages than the targeted range in the general population.

\section{Keywords: computed tomography, HIV, lung cancer, screen, smoking}

\section{Introduction}

Since the advent of combination antiretroviral therapy (cART), a shift in mortality and morbidity has been observed in people living with HIV (PLWHIV) from AIDS to non-AIDS diseases, amongst which a high proportion of malignancies [1-3]. In this population, lung cancer incidence and mortality rate are the highest among all the non-AIDS-defining malignancies [3-11]. Studies have also found increased standardized incidence ratios (SIR) of lung cancer in the HIV-infected in comparison to the general population $[4,5,8,12,13]$, with increased rates even after adjusting for smoking [14]. However, smoking is the primary trigger of lung oncogenesis in the general [15] and the HIV-infected population, as reflected by nearly $100 \%$ smoking prevalence in published case series [14,16-18]. Lung cancers will remain frequent in PLWHIV as long as smoking prevalence in this population remains high.

The randomized National Lung Screening Trial (NLST) showed a significant $20 \%$ lung cancer mortality reduction and a $6.7 \%$ overall mortality reduction in smokers from the general population aged 55 to 74 years with three annual chest low dose computed tomography (LDCT) versus radiography [19]. Due to higher incidence of lung cancer, lung cancer screening with chest CT in PLWHIV could also be beneficial. However, because of the high prevalence of pulmonary morbidities, such as infectious events, chronic obstructive pulmonary disease (COPD) and emphysema in this population [20-23], chest CT might reveal many false positive nodules or other abnormalities, leading to inappropriate invasive diagnostic procedures with increased risks of complications. Thus, studies are needed to evaluate feasibility, benefits and harms of lung cancer screening in this population. We conducted a lung cancer early diagnosis programme with a single chest CT in PLWHIV in France.

\section{Methods}

\section{Study design and participants}

This study was a multicentric prospective cohort of PLWHIV at risk for lung cancer followed for 2 years after assessment of potential lung cancer related images on a single chest CT. To be included, patients had to be infected with HIV and be smokers with a total uptake of at least 20 pack-years (possibly stopped in the last 3 years), be aged at least 40 years, to have a nadir $\mathrm{CD} 4^{+} \mathrm{T}$-cell count less than 350 cells $/ \mu l$, a current $\mathrm{CD} 4^{+}$T-cell count at least $100 \mathrm{cells} / \mu \mathrm{l}$, and a medical insurance coverage. We chose a nadir $\mathrm{CD}^{+} \mathrm{F}$ cell count below 350 cells $/ \mu \mathrm{l}$ to select patients with a history of significant immunodeficiency and a relatively long history of HIV exposure, and a last $\mathrm{CD}^{+}{ }^{+}$value at least 100 cells $/ \mu \mathrm{l}$ to minimize risk of infectious nodules. Patients were excluded in case of current active cancer or AIDS-classifying disease, lung infection within the previous two months, pregnancy, breastfeeding and contraindication to thoracic surgery. Patients were included in the study by their HIV caring physician during routine visits in 14 clinical centres in France. The study was approved by the Research Ethics Committee of Montpellier Sud-méditerranée IV (No ID-RCB: 2010-A00781-38) prior to data collection and was conducted in accordance with the standards of Ethics Committee and the Helsinki Declaration. All study participants gave written informed consent.

\section{Procedures}

All chest CT were acquired in 13 radiologic departments, all from French university-hospital centres, using multi-detector row scanners without contrast material enhancement. The entire chest from apex to posterior recesses was included at end inspiration in one breath hold according to the protocol of the study $(100 \mathrm{kVp}$, automated tube current modulation) with section thickness not greater than $1 \mathrm{~mm}$. The median effective dose derived from the product of Dose Length Product and a conversion coefficient $\left(k=0.014 \mathrm{mSv} \cdot \mathrm{mGy}{ }^{-1} \cdot \mathrm{cm}^{-1}\right)$ [24] was $2.97 \mathrm{mSV}$, interquartile range (IQR) of 1.99 to $4.49 \mathrm{mSv}$. Though there is no standardized definition of low dose in CT for lung cancer screening, actual irradiation goal is less than $2 \mathrm{mSV}(1.5 \mathrm{mSV}$ average effective dose in the NLST trial for instance [19]), to be put in perspective with a $8 \mathrm{mSV}$ or higher effective dose in diagnostic CT. The effective dose in our study was thus low to moderate according to cases. One radiologist from each centre read the CT and completed a standardized report. 
In case of a positive image on chest $\mathrm{CT}$, a standardized diagnostic workup and follow-up were suggested, adapted from the International Early Lung Cancer Action Program (IELCAP) algorithm (as detailed in efigure 1 and text in the online-only supplement, http:// links.lww.com/QAD/A819) [25]. Final decision of invasive procedures (biopsy) was left to the panel of physicians in charge of the patient. A positive chest CT result was defined as the identification of at least one solid or partly solid noncalcified pulmonary nodule not less than $5 \mathrm{~mm}$ in diameter (maximal length of the crosssectional area of the nodule), at least one nonsolid noncalcified pulmonary nodule not less than $8 \mathrm{~mm}$ in diameter, a solid endobronchial nodule or a significant adenopathy. All patients had a planned clinical evaluation 2 years after study entry. Diagnosis of lung cancer was made by histological analysis of biopsy specimens. In case of lung cancer diagnosis, patients were referred to thoracic oncologists and surgeons for standard of care. Stage classifications followed the seventh edition of the classification of malignant tumours [26].

Baseline chest CT was realized after a clinical evaluation on the same day assessed that no condition (i.e. lung infection) should postpone the exam. Investigators were advised to give information to the patient on benefits of smoking cessation. At baseline visit, demographical and immuno-virological characteristics were recorded. At the 24 months visit, numbers and types of procedures and smoking status were recorded. We also collected all interval cardiovascular morbidity, cancer diagnosis and infectious complications.

\section{Outcomes}

The predefined primary outcome was the number of histologically proven lung cancers diagnosed by the single chest CT. Secondary outcomes were the stages at diagnosis of these lung cancers, the number of diagnostic procedures realized and the description of severe adverse events related to procedures, and a description of characteristics in patients diagnosed with lung cancers.

\section{Statistical analysis}

To calculate the number of patients needed in the study, we used results from the first screening round with chest LDCT from the I-ELCAP cohort [25], in which a lung cancer prevalence of $1.07 \%$, confidence interval (CI) $95 \%$ $(0.95-1.20)$, was found in the year following baseline LDCT in patients aged 40 to 69 years. With a two to three increased risk of lung cancer in PLWHIV in comparison with patients from the general population $[4,12,13,27]$, we hypothesized lung cancer prevalence in our study to be about $3 \%$. Thus, with an $\alpha$ and a $\beta$ risk of respectively 5 and $80 \%$, the inclusion and follow-up of 2 years of 400 patients would be sufficient to detect 12 lung cancers (95\% CI: 5-19 lung cancers). With an anticipated loss to follow-up of $10 \%$, we planned to include 450 PLWHIV.
The study is registered with ClinicalTrials.gov, number NCT01207986.

\section{Role of the funding source}

The study sponsor was the ANRS (France REcherche Nord\&Sud Sida-hiv Hépatites). The funder of the study had contributed to the study design. All authors had full access to the study data and are responsible for the veracity and completeness of the data reported. The corresponding author had final responsibility for the decision to submit for publication.

\section{Results}

Between February 2011 and June 2012, 476 patients were screened for the study, and 442 patients had a CT (Fig. 1). Briefly, patients had a median age of 49.8 years, median $\mathrm{CD}^{+}$T-cell nadir and current counts of 168 and 574 cells/ $\mu 1$, respectively, $84 \%$ were men, $98 \%$ on cART, for a median duration of 13.8 years, $90 \%$ had a HIV viral load less than 50 copies $/ \mathrm{ml}$, median smoking was 30 pack-years and $35 \%$ had a history of cannabis use (Table 1). Median follow-up time after CT was 24.4 months (IQR of 22.8 to 26.4 months).

A total of 10 lung cancers were diagnosed (Table 2), amongst which nine had been visualized as positive nodules on baseline CT. Of these nine patients, eight had histologically proven lung cancers (seven of which were adenocarcinomas, and one a squamous cell carcinoma), and an additional female patient had a highly probable lung cancer suspected on a $10-\mathrm{mm}$ nodule. She underwent a negative bronchoscopy but no further biopsies as a preinvestigation diagnosis of severe arterial pulmonary hypertension precluded surgical thoracoscopy. She was treated for lung cancer with stereotaxic radiotherapy. Of the nine $\mathrm{CT}$ detected lung cancers, four were stage IA, one stage IB, one stage IIA, and three were stage IV. Two of the three patients with stage IV lung cancers had delayed diagnosis procedures after detection of a positive nodule on their CT (see online-only supplement for clinical details, http://links.lww.com/ $\mathrm{QAD} / \mathrm{A} 819)$. The prevalence of CT detected lung cancer in our population of HIV infected smokers was $2.03 \%$ (95\% CI: $0.90-3.80)$, and the number of patients needed to detect one lung cancer with the CT procedure was 49 (95\% CI: 26-111). One additional patient was diagnosed with an extended small cell lung cancer 88 weeks after his baseline CT had not identified any nodule. None of these lung cancer patients had a history of AIDS classifying disease involving the lung.

As shown in Fig. 1, 94 patients (21\%) had at least one positive image on baseline chest CT (see supplementary details on nodules in online-only supplement, http:// links.lww.com/QAD/A819). Thirty-eight patients 


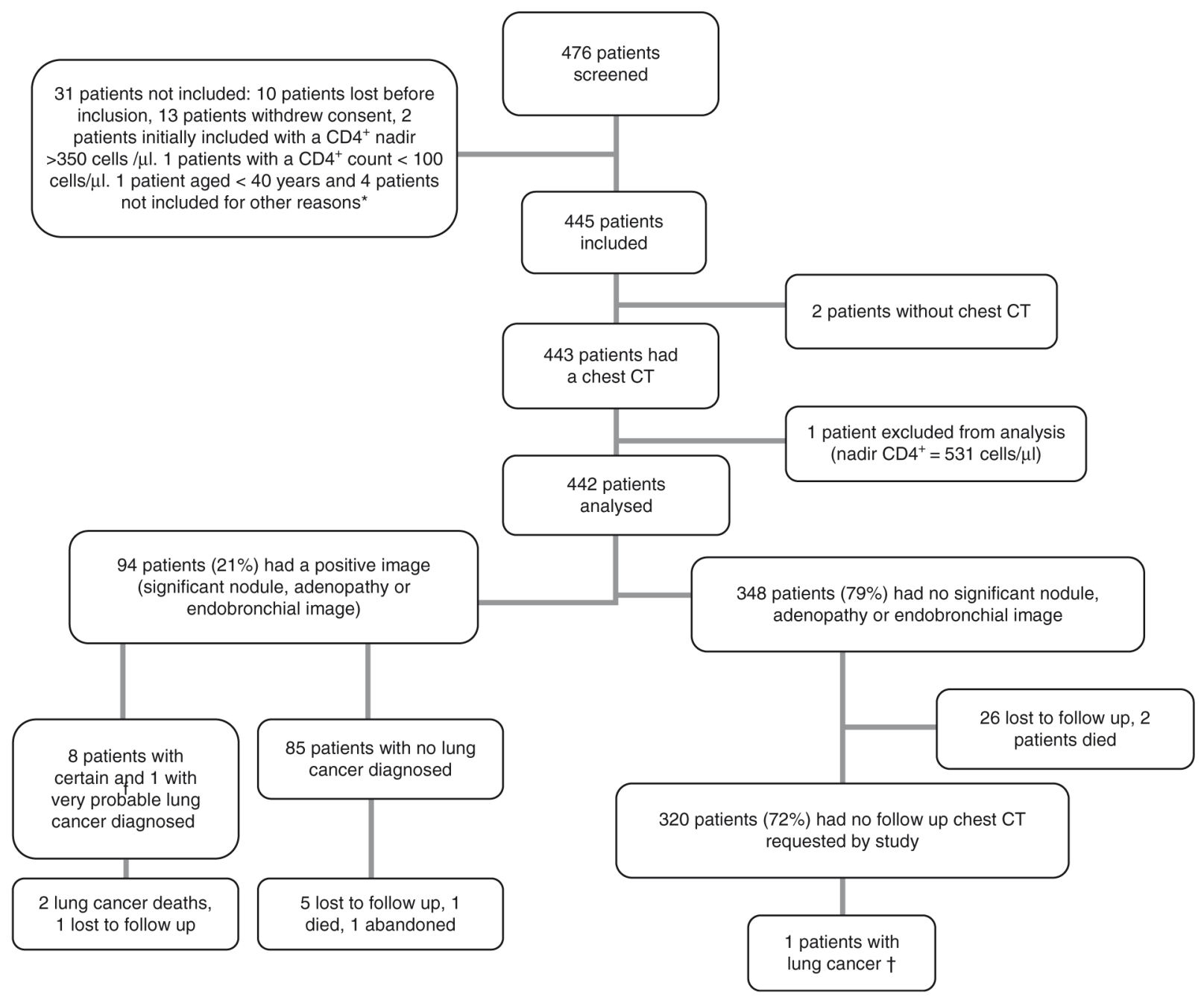

Fig. 1. Study flow chart. CT, computed tomography. *Other reasons for patients not being included were: one chest CT realized with radiological contrast injection (not allowed by study protocol), one patient fractured a bone and could not go to his scheduled $\mathrm{CT}$, and two patients had lung infections (within 2 months of study end). ${ }^{\dagger}$ This patient had a diagnosis of small cell lung cancer 88 weeks after his baseline normal CT, after clinical symptoms appeared.

(8.6\%) did not have the last visit at 2 years: five patients died, $32(7.2 \%)$ were lost to follow-up, and one abandoned the study 3 months after inclusion due to anxiety caused by the perspective of invasive diagnostic procedures for a $12-\mathrm{mm}$ solid nodule. Six lost patients had positive baseline images, and one of these six patients had a stage IA lung cancer diagnosed at month 5 , and was lost after 1 year of follow-up.

After the 442 baseline CTs, 54 patients $(12 \%)$ had a second, $22(5 \%)$ a third, $16(4 \%)$ a fourth or fifth, and two $(0.5 \%)$ a sixth protocol CT for follow-up of positive images. Eighteen diagnostic procedures in 15 patients (3.39\% of the total population, $15.96 \%$ of the CT positive patients) were undertaken (Table 3). Apart for the eight proven lung cancers, one mucosa-associated lymphoid tissue (MALT) lymphoma, one Abrikossoff tumour, and one Mycobacterium xenopi granulomatous infection were diagnosed. In four patients, invasive diagnostic procedures did not yield any final aetiology to the detected positive chest nodules. None of the diagnostic procedures yielded any serious adverse events.

During follow-up, other events attributable to smoking were cardiovascular in 12 patients $(2.7 \%)$ [myocardial ischemia $(n=8)$, stroke $(n=2)$, and symptomatic peripheral arterial disease $(n=2)]$, infectious events in 37 patients $(8.4 \%)$ [pneumonia or COPD exacerbations $(n=15)]$, new cancers, other than lung in 13 patients, of which six are associated with smoking [15]: urothelial cancer $(n=2)$, hepatocarcinoma, colon cancer, epidermoid carcinoma of the lip, and kidney cancer (one patient each). Five patients died during the study: two of consequences of their stage IV lung cancers diagnosed during the study, one of severe lung infection, one of sudden death and one of a motorbike accident. 
Table 1. Study patients' characteristics.

\begin{tabular}{|c|c|}
\hline Characteristics & Value \\
\hline Total numbers & 442 \\
\hline Age (median), (IQR) & $49.8(46.3-53.9)$ \\
\hline $40-44$ years & $74(17 \%)$ \\
\hline $45-49$ years & $153(35 \%)$ \\
\hline $50-54$ years & $134(30 \%)$ \\
\hline $55-59$ years & $51(12 \%)$ \\
\hline 60 years or more & $30(7 \%)$ \\
\hline Men $(\%)$ & $370(84)$ \\
\hline $\begin{array}{l}\text { Numbers of years of known HIV } \\
\text { infection, median (IQR) }\end{array}$ & $17.6(10.8-22.3)$ \\
\hline Nadir CD4 ${ }^{+}($cells/ $\mu \mathrm{l}),(\mathrm{IQR})$ & $168(75-256)$ \\
\hline Nadir CD4 ${ }^{+}<200$ cells/ $\mu \mathrm{l}(\%)$ & $266(60)$ \\
\hline Last $\mathrm{CD}^{+}$value, median (cells/ $\left.\mu \mathrm{l}\right)$ & $574(408-765)$ \\
\hline Last viral load < 50 copies $/ \mathrm{ml}$ & $396(90)$ \\
\hline Antiretroviral use (information for $n=439$ ) & $435(99 \%)$ \\
\hline Duration of ARV treatment, median (years) & $13.8(7.1-16.0)$ \\
\hline History of AIDS classifying disease (\%) & $124(28)$ \\
\hline History of pneumocystis pneumonia (\%) & $42(9.5)$ \\
\hline History of HCV infection (\%) & $147(33)$ \\
\hline Cigarettes (per day) (IQR) & $20(15-25)$ \\
\hline Duration of smoking (years) (IQR) & $30(28-36)$ \\
\hline Cessation of smoking within the last 3 years (\%) & $37(8)$ \\
\hline Smoking, pack-years (IQR) & $30(25-40)$ \\
\hline History of cannabis consumption ${ }^{\mathrm{a}}, n(\%)$ & $155(35)$ \\
\hline 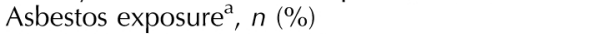 & $22(5)$ \\
\hline Alcohol intoxication ${ }^{\mathrm{a}}, n(\%)$ & $86(19)$ \\
\hline History of IVDU, $n(\%)$ & $125(28)$ \\
\hline History of cancer, $n(\%)$ & $40(9)$ \\
\hline History of COPD, $n(\%)$ & $59(13)$ \\
\hline
\end{tabular}

Details of the 40 cancers: Kaposi sarcoma $(n=12)$, non-Hodgkin Lymphoma $(n=8)$, cervical cancer $(n=4)$, anal cancer $(n=3)$, colorectal cancer $(n=2)$, melanoma $(n=2)$, bladder cancer, hepatocarcinoma, basal-cell carcinoma, lung cancer, testicular cancer, breast cancer, pancreas cancer, Hodgkin disease, head and neck cancer (one patient each). ARV, antiretroviral; COPD, chronic obstructive pulmonary disease (as reported); IQR, interquartile range; IVDU, intravenous drug use.

${ }^{a}$ As assessed by the investigators.
Of 404 patients who reached the 2 -year visit, complete data on smoking was available for 402 patients $(99.5 \%)$, of whom 368 (91\%) were active smokers at baseline. Seventy-four active smokers (20\%) had stopped smoking at their last visit. Positive baseline images were present in $57(19 \%)$ of smokers at baseline and last visit versus 19 (26\%) of patients that had ceased smoking at last visit, but distributions were not significantly different $(P=0.23)$.

\section{Discussion}

We performed a single chest CT study for early lung cancer diagnosis in a multicentre French HIV-infected cohort of smokers and found a 2.03\% (95\% CI, 0.90$3.80)$ prevalence of lung cancer and a $21 \%$ prevalence of positive images. We also evidenced that six of nine lung cancers with baseline positive images on their CT were diagnosed at early stages. Study adherence was high, and diagnostic procedures were few and safe.

Our result of nine CT detected lung cancers in our HIVinfected smoking population with a $\mathrm{CD} 4^{+}$T-cell nadir below 350 cells $/ \mu$ is high. Whether our result reflects increased risk of lung cancer in HIV-infected smokers in comparison with smokers of similar age from the general population is out of the scope of our study in the absence of a control group, but an increased risk is supposedly mediated through persistent decreased tumoural immunovigilance despite cART. Other important mechanisms are chronic lung damage due to clinical or subclinical repeated pulmonary infections and enhanced inflammation $[28,29]$. In the French Hospital Database on HIV

Table 2. Characteristics of patients with lung cancers.

\begin{tabular}{|c|c|c|c|c|c|c|c|c|c|c|}
\hline Patient & 81008 & 67003 & 67029 & $90048^{b}$ & 57017 & 49013 & 75062 & 75006 & 57016 & 67016 \\
\hline Age & 45 & 46 & 49 & 50 & 50 & 52 & 52 & 54 & 56 & 58 \\
\hline Sex & M & $\mathrm{F}$ & M & M & $\mathrm{F}$ & M & M & M & M & $\mathrm{F}$ \\
\hline Smoking (pack-years) & 30 & 52 & 45 & 40 & 27 & 35 & 60 & 28 & 34 & 21 \\
\hline Smoking (years) & 30 & 35 & 30 & 32 & 36 & 37 & 34 & 37 & 39 & 42 \\
\hline Cannabis use & Yes & Yes & No & No & No & Yes & Yes & Yes & No & Yes \\
\hline COPD & No & Yes & No & No & No & Yes & Yes & Yes & Yes & Yes \\
\hline Viral load (copies/ml) & $<40$ & $<40$ & $<40$ & $<20$ & 61 & $<40$ & 43 & $<20$ & $<40$ & $<40$ \\
\hline Nadir CD4 ${ }^{+}($cells $/ \mu \mathrm{l})$ & 160 & 132 & 321 & 1 & 60 & 236 & 214 & 71 & 201 & 218 \\
\hline $\mathrm{CD}^{+}{ }^{\text {value }}($ cells $/ \mu \mathrm{l})$ & 637 & 597 & 378 & 448 & 590 & 568 & 859 & 345 & 480 & 573 \\
\hline $\mathrm{CD}^{+} / \mathrm{CD}^{+}$ratio & 0.58 & 0.84 & 0.88 & 0.34 & 1.02 & 0.47 & 2 & 0.42 & 1 & 0.54 \\
\hline Positive LDCT image & Yes & Yes & Yes & No & Yes & Yes & Yes & Yes & Yes & Yes \\
\hline Lung cancer histology & AdenoK & AdenoK & AdenoK & Small cell & AdenoK & AdenoK & AdenoK & Squamous cell & AdenoK & No histology \\
\hline Lung cancer stage & IA & IV & IIA & Extended & IV & IV & IA & IA & IB & $I A^{a}$ \\
\hline $\begin{array}{l}\text { Last LDCT before } \\
\text { biopsy (months) }\end{array}$ & M1 & M18 & M12 & MO & MO & MO & MO & M3 & M3 & M24 \\
\hline $\begin{array}{l}\text { Time till cancer } \\
\text { diagnosis (weeks) }\end{array}$ & 23 & 76 & 70 & 88 & 12 & 66 & 7 & 23 & 7 & NA \\
\hline
\end{tabular}

AdenoK, adenocarcinoma of the lung; Squamous cell, squamous cell carcinoma of the lung.

aExtension established with radiological evaluation. COPD, chronic obstructive pulmonary disease (as measured by spirometry or reported); IVDU, intravenous drug use; NA, non-applicable.

${ }^{\mathrm{b}}$ This patient had a normal baseline $\mathrm{CT}$, and became symptomatic during follow-up with a diagnosis of small cell lung cancer 88 weeks after inclusion. 
Table 3. Diagnostic procedures induced by the discovery of a positive image on computed tomography.

\begin{tabular}{lllll}
\hline Patient & 1st invasive procedure & 2nd invasive procedure & Lung cancer diagnosis & Alternative histological diagnosis \\
\hline 32007 & Thoracic surgery & No & No & MALT lymphoma \\
32033 & Fine-needle CT biopsy & Thoracic surgery & No & Mycobacterium xenopi infection \\
49013 & Bronchoscopy & No & AdenoK & No \\
57016 & Fine-needle CT biopsy & No & AdenoK & No \\
57017 & Fine-needle biopsy & No & AdenoK & No \\
67003 & Fine-needle CT biopsy & Fine needle CT biopsy & AdenoK & No \\
67016 & Bronchoscopy & No & Very probable & No \\
67029 & Thoracic surgery & No & AdenoK & AAH \\
75006 & Thoracic surgery & No & No & No \\
75039 & Thoracic surgery & No & AdenoK & Abrikossoff tumour \\
75062 & Thoracic surgery & No & AdenoK & No \\
76032 & Bronchoscopy and gastroscopy & No & No & No \\
81008 & Thoracic surgery & No & No & \\
90013 & Bronchoscopy & No & & \\
90031 & Bronchoscopy & No & & \\
\hline
\end{tabular}

AAH, atypical adenomatous hyperplasia; AdenoK, adenocarcinoma of the lung; MALT, mucosa-associated lymphoid tissue; Squamous cell, squamous cell carcinoma of the lung.

(ANRS CO4 FHDH Study), an association between incidence of lung cancer and chronic immunodeficiency was observed with a dose relationship (i.e. the higher the $\mathrm{CD} 4{ }^{+}$cell count, the lower the incidence of cancer) [30]. In another study from the same database, incidence was similar in comparison with the general population only in patients that reached a lymphocyte $\mathrm{CD} 4^{+}$cell count above 500 cells $/ \mu 1$ [8]. Despite high $\mathrm{CD}^{+}{ }^{+}$cell counts at inclusion in our patients, all patients had a long history of immunodeficiency as reflected by the low nadir values, and most patients with lung cancer had a low $\mathrm{CD} 4^{+}$, $\mathrm{CD}^{+}$lymphocyte ratio at inclusion, reflecting only partial immune recovery (Table 2).

The number of CT detected lung cancers may have been less than the real numbers of lung cancers in our study. Indeed, we realized a single chest CT and may have not, in some cases, diagnosed asymptomatic cancerous nodules below $5 \mathrm{~mm}$. However, numbers of under diagnosed lung cancers were probably low, as the probability for a patient with a nodule not more than $5 \mathrm{~mm}$ of developing lung cancer in the following 2 years was $0.4 \%[0.2-0.7]$ in a recent study, not significantly different from the probability of lung cancer in patients without any visible nodule [31].

Eight of the 10 lung cancers occurred in patients younger than 55 years. This result is notable, as these patients would have been missed if NLST guidelines for lung cancer screening had been followed. Performing chest CT in our study in patients over 45 years would not have missed any lung cancers, a result in coherence with epidemiological studies of excess lung cancer risk in PLWHIV in comparison with the general population starting between the ages of 40 and 50 years [32]. However, screening PLWHIV too young is probably not efficient. A study from Baltimore screened with five annual chest LDCT 224 current/former HIV-infected smokers aged 25 years or older (median age 48 years,
IQR [44-53]), and did not detect any lung cancers [33]. Our results are also partly explained by the age distribution of our patients, which reflects HIV epidemiology, as nearly two-thirds were between 45 and 54 years. However, accelerated and accentuated aging in PLWHIV who smoke could have played a significant role in the age distribution of lung cancers in our study. Accelerated aging results from pathways and mechanisms common to the aging process, whilst accentuated aging results from HIV infection behaving as an additional risk factor, thus accentuating the risk of lung cancer at every age in PLWHIV who smoke [34]. A comparison of North American HIV and cancer registries showed that median age of lung cancer diagnosis was 4 years younger in PLWHIV when both populations were standardized on age, suggesting moderate accelerated aging [35]. Data from the VACS cohort showed that mean adjusted-age occurrence of non-AIDS-defining malignancies was similar in HIVinfected versus uninfected patients, but that incidence was significantly increased through all age groups, reflecting accentuated aging [36].

One of the concerns of lung cancer screening in HIVinfected smokers was the possibility of a high number of false positive images identified on chest CT due to former or active lung infections, emphysema or bronchiolitis, leading to subsequent high numbers of CT follow-up scans and invasive diagnostic procedures. Though these rates of false positive images depend on numerous factors including participants' characteristics, positive nodule definition and follow-up algorithms, the $21 \%$ prevalence of positive images in our study was in the range (13 to 29\%) of most published lung cancer screening studies in the targeted general population settings $[19,25,37,38]$. Moreover, the number of invasive procedures was low (18 procedures in 15 of patients) in our study and in four cases permitted histological alternative diagnosis. 
We did not find any impact of positive CT images on smoking cessation, contrary to some studies in the general population [39-41]. Inclusion in a lung cancer diagnosis programme may have less impact on smoking abstinence in PLWHIV who regularly received counselling on risk reductions, including smoking hazards, by their physicians than in patients included in lung cancer screening programs in the general population [41]. Patients from the general population included in lung cancer screening studies are usually 'healthy' smokers, contacted by means of advertisements, direct mailing or use of mass media $[38,42,43]$. These patients, volunteering to undergo screening, may be more willing to quit smoking and may strongly benefit from their first encounters with health professionals to achieve this goal, further enhanced by the presence of positive images.

As suggested by the numerous smoking-related morbidities in lung cancer screening studies in the general population [19] and in our study, quitting smoking is the most efficient intervention to diminish mortality in smokers, whether HIV-infected or not.

Our study has limitations. First, some characteristics were insufficiently quantified, such as cannabis use. Second, quality of life questionnaires, evaluating the impact on anxiety of positive images, were not administered. Third, as a nonrandomized study, we could not evaluate whether chest CT increased survival and diminished lung cancer mortality in PLWHIV, and follow-up of patients after their baseline chest CT was 2 years only. Fourth, our multicentre study took place in university hospitals, with expertise in CT nodule management, and results may not be generalizable to all clinical settings. Finally, lung cancer induced by radiation is a possible long-term adverse effect that could not be assessed in our study, and would be important to estimate if HIV-infected patients are to be screened at younger ages than patients from the general population, as there is a known interaction between radiation and smoking on lung cancer risk [44]. Upholding this, a substantial number of participants underwent numerous chest CT and additional diagnostic radiological procedures in our study.

Despite these caveats, our study has important implications for lung cancer screening in PLWHIV at high risk. We showed that lung cancer early diagnosis with CT in HIV smokers is feasible. We found an acceptable rate of false positive images and no reported adverse events. Also, adherence to study protocol was high. Finally, lung cancer screening should benefit PLWHIV younger than 55 years who smoke and who have a history of significant immunodeficiency, possibly starting as early as 45 years.

In conclusion, within the 2-year follow-up, we found that chest CTwas a safe and effective procedure to detect lung cancer, most of them at early stages, in HIV-infected heavy smokers, aged over 45 years, with history of nadir
$\mathrm{CD} 4^{+}$below 350 cells $/ \mu \mathrm{l}$ and current $\mathrm{CD} 4^{+}$above 100 cells $/ \mu 1$. Screening of HIV-infected smokers with a significant history of immunodeficiency for lung cancer revealed a substantial number of cancers at younger ages than the targeted age range in the general population.

\section{Acknowledgements}

We thank the trial participants and the coordinators, engineers and technicians who made this study possible: Suzanne Izard, Jonathan Lalet, Sandrine CouffinCadiergues, Mylène Quesnoy, Carole Damien and Bruno Granouillac. We also thank the ANRS EP48 HIV CHEST study safety board: Armelle Lavolé, François Boué, Nicolas Nagot, Jean-Yves Gaubert. The ANRS EP48 HIV CHEST Study Team Hôpital Gustave Dron de Tourcoing: Yazdan Yazdanpanah, Antoine Cheret, Faïza Ajana, Isabelle Alcaraz, Véronique Baclet, Hugues Melliez, Michel Valette, Nathalie Viget, Xavier De La Tribonniere, Thomas Huleux, Séverine Bonne Séverine, Raphaël Biekre, Armelle Pasquet, Christophe Allienne, Jean Marie Behra, Agnès Meybeck, Emmanuelle Aissi. Hôpital Avicenne de Bobigny: Sophie Abgrall, Olivier Bouchaud, Régine Barruet, François Rouges, Tania Kandel, Fréderic Mechai, Pierre-Yves Brillet, Michel Brauner, Hôpital l'Archet de Nice: Pierre Dellamonica, Francine De Salvador, Eric Cua, Anne Leplatois, Alissa Naqvi, Jacques Durant, Carole Ceppi, Frédéric Sanderson, Eric Rosenthal, Madleen Chassang, Patrick Chevallier, Brigitte Dunais. Hôpital Pontchailloux de Rennes: Pierre Tattevin, Hervé Lena, Pierre-Axel Lentz, Christian Michelet, Cédric Arvieux, Mathieu Revest, Faouzi Soula, Jean-Marc Chapplain, Hélène Leroy, Catherine Meunier. Hôpital Ste Marguerite de Marseille: Isabelle Poizot-Martin, Olivia Faucher, Amélie Menard, Sylvie Bregigeon, Perrine Geneau de Lamarliere, Pierre Champsaur, Olivier durieux, Nicolas Cloarec. Hôpital Hotel Dieu de Nantes: François Raffi, Clotilde Allavena, Nicolas Feuillebois, Olivier Mounoury, Sabelline Bouchez, Eric Billaud, Véronique Reliquet, Bénédicte Bonnet, Cécile Brunet, Patrick Point, David Boutoille, Pascale Morineau Le Houssine, Anne Sophie Delemazure. Hôpital Necker de Paris: Claudine Duvivier, Emilie Catherinot, Michka Shoai Tehrani, Sylvain Poiree. Hôpital Foch de Suresnes: David Zucman, Catherine Majerholc, Louis-Jean Couderc, François Mellot, Antoine Sherrer. Hôpital La Croix Rousse de Lyon: Tristan Ferry, Joseph Koffi, André Boibieux, Patrick Miailhes, Laurent Cotte, Thomas Perpoint, Joanna Lippman, Claude Augustin Norman, Francois Biron, Agathe Senechar, Florence Ader. Hôpital Tenon de Paris: Gilles Pialloux, Thomas L'Yavanc, Laurence Slama, Julie Chas, Sophie Le Nagat, Antoine Khalil, Marie France Carette. Hôpital St André de Bordeaux: Fabrice Bonnet, Philippe Morlat, Denis Lacoste, Marie Vandenhende, Marie Catherine Receveur, Francois Paccalin, Sabrina 
Caldato, Noëlle Bernard, Mojgan Hessemfar, Thierry Pistone, Denis Malvy, Pierre thibaut, Marie Carmen Pertusa, Olivier Cornelou, Francois Laurent, Patrick Mercie, Isabelle Faure, Denis dondia, Cedric Martell, Pierre Duffau. Hôpital Carémeau de Nîmes: Jean Marc Mauboussin, Claudine Barbuat, Isabelle Rouanet, Liliane Metge. Hôpital Gui de Chauliac de Montpellier: Jacques Reynes, Vincent Le Moing, Jean-Marc Jacquet, Nadine Atoui, Mickael Loriette, David Morquin, Vincent Fauchere, Carine Favier, Corinne Merle, Vincent Baillat, Antoine Da Silva, Rachid Mansouri, Christina Psomas, Sébastien Bommart, Hélène Kovacsik-Vernhet, JeanLouis Pujol, Xavier Quantin, Maurice Hayot.

Contributors: A.M. was the lead investigator, designed the trial, developed the protocol, interpreted the statistical analysis and wrote the manuscript. S.E.D. did the statistical analysis. V.L.M. was the scientific lead and methodologist of the study. S.B., M.B., P.L. helped to plan radiological standardized interpretation. L.M. was the project manager. A.M., V.L.M., J.R., S.A., X.Q., S.B., and P.T. were members of the scientific committee. All authors reviewed, revised, and approved the final manuscript.

Funding source: ANRS (France REcherche Nord\&Sud Sida-hiv Hépatites)

\section{Conflicts of interest}

The authors report no conflicts of interest.

\section{References}

1. Smith CJ, Ryom L, Weber R, Morlat P, Pradier C, Reiss P, et al Trends in underlying causes of death in people with HIV from 1999 to 2011 (D:A:D): a multicohort collaboration. Lancet 2014; 384:241-248.

2. Kowalska JD, Reekie J, Mocroft A, Reiss P, Ledergerber B, Gatell $\mathrm{J}$, et al. Long-term exposure to combination antiretroviral therapy and risk of death from specific causes: no evidence for any previously unidentified increased risk due to antiretroviral therapy. AIDS 2012; 26:315-323.

3. Morlat P, Roussillon C, Henard S, Salmon D, Bonnet F, Cacoub $\mathrm{P}$, et al. Causes of death among HIV-infected patients in France in 2010 (national survey): trends since 2000. AIDS 2014; 28:1181-1191.

4. Bedimo RJ, McGinnis KA, Dunlap M, Rodriguez-Barradas MC, Justice AC. Incidence of non-AIDS-defining malignancies in HIV-infected versus noninfected patients in the HAART era: impact of immunosuppression. J Acquir Immune Defic Syndr 2009; 52:203-208.

5. Robbins HA, Shiels MS, Pfeiffer RM, Engels EA. Epidemiologic contributions to recent cancer trends among HIV-infected people in the United States. AIDS 2014; 28:881-890.

6. Lanoy E, Spano JP, Bonnet F, Guiguet M, Boue F, Cadranel J, et al. The spectrum of malignancies in HIV-infected patients in 2006 in France: the ONCOVIH study. Int / Cancer 2011; 129:467-475.
7. Shiels MS, Pfeiffer RM, Gail MH, Hall HI, Li J, Chaturvedi AK, et al. Cancer burden in the HIV-infected population in the United States. I Natl Cancer Inst 2011; 103:753-762.

8. Hleyhel M, Hleyhel M, Bouvier AM, Belot A, Tattevin P, Pacanowski J, et al., Cancer Risk Group of the French Hospital Database on HIV. Risk of non-AIDS-defining cancers among HIV-1-infected individuals in France between 1997 and 2009: results from a French cohort. AIDS 2014; 28:2109-2118.

9. Gotti D, Raffetti E, Albini L, Sighinolfi L, Maggiolo F, Di Filippo $\mathrm{E}$, et al. Survival in HIV-infected patients after a cancer diagnosis in the cART Era: results of an italian multicenter study. PLoS One 2014; 9:94768.

10. Shiels MS, Cole SR, Mehta SH, Kirk GD. Lung cancer incidence and mortality among HIV-infected and HIV-uninfected injection drug users. I Acquir Immune Defic Syndr 2010; 55:510515.

11. Chaturvedi AK, Pfeiffer RM, Chang L, Goedert JJ, Biggar RJ, Engels EA. Elevated risk of lung cancer among people with AIDS. AIDS 2007; 21:207-213.

12. Engels EA, Pfeiffer RM, Goedert JJ, Virgo P, McNeel TS, Scoppa $\mathrm{SM}$, et al. Trends in cancer risk among people with AIDS in the United States 1980-2002. AIDS 2006; 20:1645-1654.

13. Grulich $A E$, van Leeuwen $M T$, Falster $M O$, Vajdic $C M$. Incidence of cancers in people with HIV/AIDS compared with immunosuppressed transplant recipients: a meta-analysis. Lancet 2007; 370:59-67.

14. Sigel K, Wisnivesky J, Gordon K, Dubrow R, Justice A, Brown $\mathrm{ST}$, et al. HIV as an independent risk factor for incident lung cancer. AIDS 2012; 26:1017-1025.

15. Agudo A, Bonet C, Travier N, Gonzalez CA, Vineis P, Bueno-deMesquita $\mathrm{HB}$, et al. Impact of cigarette smoking on cancer risk in the European prospective investigation into cancer and nutrition study. I Clin Oncol 2012; 30:4550-4557.

16. Lavole A, Chouaid C, Baudrin L, Wislez M, Raguin G, Pialoux $\mathrm{G}$, et al. Effect of highly active antiretroviral therapy on survival of HIV infected patients with nonsmall-cell lung cancer. Lung Cancer 2009; 65:345-350.

17. Makinson A, Tenon JC, Eymard-Duvernay S, Pujol IL, Allavena $C$, Cuzin $L$, et al. Human immunodeficiency virus infection and nonsmall cell lung cancer: survival and toxicity of antineoplastic chemotherapy in a cohort study. I Thorac Oncol 2011; 6:1022-1029.

18. Brock MV, Hooker CM, Engels EA, Moore RD, Gillison ML, Alberg $\mathrm{AJ}$, et al. Delayed diagnosis and elevated mortality in an urban population with HIV and lung cancer: implications for patient care. I Acquir Immune Defic Syndr 2006; 43:47-55.

19. Aberle DR, Adams AM, Berg CD, Black WC, Clapp JD, Fagerstrom RM, et al. Reduced lung-cancer mortality with low-dose computed tomographic screening. N Engl / Med 2011; 365:395-409.

20. Samperiz G, Guerrero D, Lopez M, Valera J, Iglesias A, Rios A et al. Prevalence of and risk factors for pulmonary abnormalities in HIV-infected patients treated with antiretroviral therapy. HIV Med 2014; 15:321-329.

21. Crothers K, Huang L, Goulet JL, Goetz MB, Brown ST, Rodriguez-Barradas MC, et al. HIV infection and risk for incident pulmonary diseases in the combination antiretroviral therapy era. Am J Respir Crit Care Med 2010; 183:388-395.

22. Crothers K, Butt AA, Gibert CL, Rodriguez-Barradas MC, Crystal $S$, Justice AC. Increased COPD among HIV-positive compared to HIV-negative veterans. Chest 2006; 130:1326-1333.

23. Makinson A, Hayot M, Eymard-Duvernay S, Quesnoy M, Raffi F, Thirard $\mathrm{L}$, et al. High prevalence of undiagnosed COPD in a cohort of HIV-infected smokers. Eur Respir / 2014; 45:828831.

24. Huda W, Ogden KM, Khorasani MR. Converting dose-length product to effective dose at CT. Radiology 2008; 248:9951003.

25. Henschke $\mathrm{Cl}$, Yankelevitz DF, Libby DM, Pasmantier MW Smith JP, Miettinen OS. Survival of patients with stage I lung cancer detected on CT screening. N Engl / Med 2006; 355:1763-1771.

26. Lababede O, Meziane M, Rice T. Seventh edition of the cancer staging manual and stage grouping of lung cancer: quick reference chart and diagrams. Chest 2011; 139:183-189.

27. Dal Maso L, Polesel I, Serraino D, Lise M, Piselli P, Falcini $F$, et al. Pattern of cancer risk in persons with AIDS in Italy in the HAART era. Br / Cancer 2009; 100:840-847. 
28. Hessol NA, Martinez-Maza O, Levine AM, Morris A, Margolick $J B$, Cohen $\mathrm{MH}$, et al. Lung cancer incidence and survival among HIV-infected and uninfected women and men. AIDS 2015; 29:1183-1193.

29. Shebl FM, Engels EA, Goedert IJ, Chaturvedi AK. Pulmonary infections and risk of lung cancer among persons with AIDS. $)$ Acquir Immune Defic Syndr 2010; 55:375-379.

30. Guiguet M, Boue F, Cadranel I, Lang JM, Rosenthal E, Costagliola D. Effect of immunodeficiency, HIV viral load, and antiretroviral therapy on the risk of individual malignancies (FHDH-ANRS CO4): a prospective cohort study. Lancet Oncol 2009; 10:1152-1159.

31. Horeweg N, van Rosmalen I, Heuvelmans MA van der Aalst CM, Vliegenthart R, Scholten ET, et al. Lung cancer probability in patients with CT-detected pulmonary nodules: a prespecified analysis of data from the NELSON trial of low-dose CT screening. Lancet Oncol 2014; 15:1332-1341.

32. Robbins HA, Pfeiffer RM, Shiels MS, Li J, Hall HI, Engels EA Excess cancers among HIV-infected people in the United States. I Natl Cancer Inst 2015; 107:.

33. Hulbert A, Hooker CM, Keruly JC, Brown T, Horton K, Fishman $\mathrm{E}$, et al. Prospective CT screening for lung cancer in a high-risk population: HIV-positive smokers. I Thorac Oncol 2014; 9:752-759.

34. Pathai S, Bajillan H, Landay AL, High KP. Is HIV a model of accelerated or accentuated aging? / Gerontol A Biol Sci Med Sci 2014; 69:833-842.

35. Shiels MS, Pfeiffer RM, Engels EA. Age at cancer diagnosis among persons with AIDS in the United States. Ann Intern Med 2010; 153:452-460.

36. Althoff KN, McGinnis KA, Wyatt CM, Freiberg MS, Gilbert C, Oursler $\mathrm{KK}$, et al. Comparison of risk and age at diagnosis of myocardial infarction, end-stage renal disease, and non-AIDSdefining cancer in HIV-infected versus uninfected adults. Clin Infect Dis 2015; 60:627-638.
37. van Klaveren RJ, Oudkerk M, Prokop M, Scholten ET, Nackaerts $\mathrm{K}$, Vernhout $\mathrm{R}$, et al. Management of lung nodules detected by volume CT scanning. N Engl / Med 2009; 361:2221-2229.

38. Pedersen JH, Ashraf H, Dirksen A, Bach K, Hansen H, Toennesen $\mathrm{P}$, et al. The Danish randomized lung cancer $\mathrm{CT}$ screening trial-overall design and results of the prevalence round. J Thorac Oncol 2009; 4:608-614.

39. Styn MA, Land SR, Perkins KA, Wilson DO, Romkes M, Weissfeld JL. Smoking behavior 1 year after computed tomography screening for lung cancer: effect of physician referral for abnormal CT findings. Cancer Epidemiol Biomarkers Prev 2009; 18:3484-3489.

40. Townsend CO, Clark MM, Jett JR, Patten CA, Schroeder DR Nirelli LM, et al. Relation between smoking cessation and receiving results from three annual spiral chest computed tomography scans for lung carcinoma screening. Cancer 2005; 103:2154-2162.

41. Tammemagi MC, Berg CD, Riley TL, Cunningham CR, Taylor $\mathrm{KL}$. Impact of lung cancer screening results on smoking cessation. I Nat/ Cancer Inst 2014; 106:dju084.

42. National Lung Screening Trial Research Team. Aberle DR, Berg CD, Black WC, Church TR, Fagerstrom RM, et al. The National Lung Screening Trial: overview and study design. Radiology 2011; 258:243-253.

43. van lersel CA, de Koning HJ, Draisma G, Mali WP, Scholten ET Nackaerts $K$, et al. Risk-based selection from the general population in a screening trial: selection criteria, recruitment and power for the Dutch-Belgian randomised lung cancer multislice CT screening trial (NELSON). Int / Cancer 2007; 120:868-874.

44. Brenner DJ. Radiation risks potentially associated with lowdose CT screening of adult smokers for lung cancer. Radiology 2004; 231:440-445. 